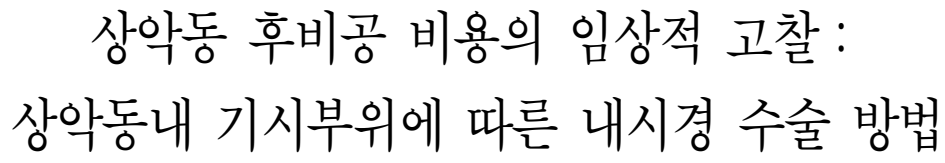

부산대학교 의학전문대학원 이비인후과학교실

윤빛나·조규섭 · 이종길 · 이재은 · 노환중

\title{
A Clinical Analysis of Antrochoanal Polyp : Endoscopic Operation Technique according to Origin Site in the Maxillary Antrum
}

\author{
Bit-Na Yoon, MD, Kyu-Sup Cho, MD, Jong-Kil Lee, MD, Jae-Eun Lee, MD and Hwan-Jung Roh, MD \\ Department of Otorhinolaryngology, Pusan National University School of Medicine, Busan, Korea
}

\begin{abstract}
- ABSTRACT -
Background and Objectives : The aims of thid study were to analyze the clinical characteristics of antrochoanal polyps (ACPs) and find proper operative method. Materials and Methods : This is a retrospective review of 48 patients performed ESS and puncture and shaving technique for antrochoanl polyp. Clinical symptoms, correlation with allergy and sinusitis, origion site of ACP, passage site of ACP (natural ostium vs. accessory ostium), operative technique of antrochoanal polyp according to origin site, recurrence according to operative technique, complications were analyzed. Results : Nasal obstruction was the most common symptom in our study. $61.3 \%$ of patients with ACP showed allergy in MAST, nasal cytology and total serum IgE test. 56.3\% of ACPs herniated into the nasal cavity through the natural ostium, $41.7 \%$ of ACPs herniated through the accessory ostium. All 48 patients underwent ESS, and among of them, 12 patients underwent operation using "puncture and shaving" technique. The ACPs in this study originated from the lateral wall (30.4\%), anterior wall $(8.8 \%)$, posterolateral wall $(13 \%)$, posteroinferior wall $(13 \%)$, inferior wall $(13 \%)$, medial wall $(4.4 \%)$, superior wall $(4.4 \%)$ of maxillary antrum in the subgroup of patients who underwent conventional ESS. In the other subgroup of patients who underwent "puncture and shaving" technique, the ACPs originated from the lateral wall $(37.5 \%)$, anterior wall $(37.5 \%)$, posterolateral wall $(12.5 \%)$, posterior wall $(12.5 \%)$ of maxillary antrum. The recurrence rate following surgery using "puncture and shaving technique" in patients with ACPs was significantly low than the patients who underwent conventinal ESS. Conclusion : The endoscopic approach to the removal of ACPs has proven to be a safe and effective means of managing ACPs. When the ACPs originated from the posterior wall or lateral wall around posteral wall of maxillary antrum, conventional ESS can be a safe and effective means of managing ACPS, but if the ACPs originated from the anterior wall or lateral wall around anterior wall of maxillary antrum, "puncture and shaving" tehnique is needed for complete removal of ACPs. (J Clinical Otolaryngol 2007;18:224-228)
\end{abstract}

KEY WORDS : Nasal polyps · Maxillary sinus · Endoscopy $\cdot$ Puncture $\cdot$ Analysis.

논문접수일 : 2007년 8월 19일

심사완료일 : 2007년 10월 17일

교신저자 : 조규섭, 602-739 부산광역시 서구 아미동 1가 10번지 부산대학교 의학전문대학원 이비인후과학교실

전화 : (051) 240-7335·전송 : (051) 246-8668 E-mail : ckssmj@hanmail.net 


\section{서 론}

상악동 후비공 비용(antrochoanal polyp)은 상악동 점 막에서 기원하여 상악동의 자연공 혹은 부공을 통해 빠 져나와 후비공과 비인강까지 자라나는 가성 종양이다. ${ }^{1)}$ 대개 일측성으로 발생하며, 전체 비용의 3 6\% 정도로 드문 질환이지만 소아에서는 $33 \%$ 까지 그 빈도가 증가 하는 질환이다. ${ }^{1-3)}$

상악동 후비공 비용의 수술 방법은 과거에는 주로 단 순 절제술, Caldwell-Luc 수술, 골성형 상악동 수술 등 이 주로 사용되었으나 최근에는 술후 특별한 합병증이 없고 안전하고 쉽게 사용할 수 있는 부비동 내시경 수술 이 많이 사용되고 있다. 특히 최근에는 견치와 접근법으 로 회전식 흡입기를 이용하여 자연공을 통해 제거하기 어려운 병적 점막을 제거하는 "puncture and shaving" 방법으로 부비동 내시경 수술만으로는 비용의 완전 제 거가 불가능한 경우에 대부분의 병변 제거가 가능하고 재 발의 가능성을 줄일 수 있다고 보고되었다. ${ }^{4-8)}$ 최근까 지 상악동 후비공 비용에 대한 방사선학적, ${ }^{9) 10)}$ 조직병리 학적, ${ }^{11)}$ 수술적 접근방법 ${ }^{24-6) 12)}$ 에 대한 국내외 연구와 보고들이 있어 왔으나, 전반적인 임상적 특징 및 비용의 기시부위에 따른 적절한 내시경적 수술방법과 재발에 대 한 연구는 드문 실정이다. 이에 저자들은 상악동 후비공 비용으로 부비동 내시경 수술을 시행 받았던 환자를 대 상으로 임상적 특징 및 알레르기 및 부비동염 동반 여부, 비용의 기시부위, 수술방법에 따른 비용의 완전 제거 및 수술 후 재발과 합병증에 대해 알아보고자 하였다.

\section{대상 및 방법}

1995년부터 2007년까지 이비인후과에 내원하여 병 력과 이학적 검사, 비강 내시경 검사 및 비 · 부비동 전산 화 단층 촬영을 통해 상악동 후비공 비용으로 진단 받고 수술을 받은 환자 중 1 년 이상 추적 관찰이 가능했던 48 명의 환자를 후향적으로 분석하였다. 임상 증상, 알레르 기 및 부비동염 동반여부, 상악동 내 비용의 비강으로의 탈출경로, 비용의 기시부위, 수술방법과 재발 여부, 술후 합병증 등을 알아보았다. 연령 분포는 3 71세(평균 17.3 세) 였으며, 남자가 32 명, 여자가 16 명 이었다. 임상 증
상은 환자가 호소하는 주된 증상 1 가지에 대해 분석하 였으며, 발생한 상악동 부위는 우측 21예, 좌측 26예, 양측 1 예였다.

수술 방법은 일반적인 부비동 내시경 수술을 시행하여 비강 내 비용을 제거하고 상악동의 자연 개구부를 최대한 넓힌 후 $30^{\circ}$ 나 $70^{\circ}$ 내시경을 통해 상악동 내에 남아 있는 비용의 기시부위를 확인하고 여러 가지 기구를 이 용하여 비용의 상악동 부분을 제거하였다. 이런 방법으 로도 상악동 내 잔존 비용 조직과 비후된 병적 조직을 제거하지 못하는 경우는 보조적으로 견치와 천공을 통해 회전식흡입기를 사용한 상악동내시경수술 즉 "puncture and shaving" 기법을 사용하였다. 환자의 추적관찰기간 은 $12 ~ 30$ 개월(평균 24.5 개월)이었다.

\section{결 과}

\section{임상증상}

내원 당시 주증상은 일측성 비폐색이 39 명 $(81.3 \%)$ 으 로 가장 많았으며, 비루 6명(12.5\%) 후비루 1명(2.1\%) 비출혈 1명 $(2.1 \%)$ 코골이 1명(2.1\%)이었다. 비폐색을 호소하는 39명중 13 명은 비루가 동반되었으며, 1 명은 두 통, 1명은 협부통증이 동반되었다(Table 1).

\section{알레르기 동반여부}

48 명의 환자 중 31 명의 환자에서 MAST, 비세포검사 (nasal cytology), 혈청 총 $\operatorname{IgE}$ 검사를 통해 알레르기 동 반여부를 평가하였다. 19명(61.3\%)은 특정 알레르기 항 원에 양성반응을 보였으며 12 명 $(38.7 \%)$ 은 음성이었다.

\section{부비동염 동반여부}

모든 예에서 편측의 상악동 및 후비공에 연부조직 음 영으로 채워져 있었으며 특징적으로 이들 병변 내에 상

Table 1. Presenting symptoms with antroc hoa nal polyp

\begin{tabular}{lc}
\hline \multicolumn{1}{c}{ Symptoms } & No. (\%) \\
\hline Unilateral nasal obstruction & $39(81.3)$ \\
Rhinonhea & $6(12.5)$ \\
Post nasal dripping & $1(2.1)$ \\
Epistaxis & $1(2.1)$ \\
Snoring & $1(2.1)$ \\
\hline Total & $48(100)$ \\
\hline
\end{tabular}


악동 자연공이 넓혀져 있는 소견이 관찰되었다. 후비공 비 용과 동측의 상악동을 제외한 부비동염이 동반된 경우는 19 명이었으며, 반대측의 경우도 16 명에서 부비동염이 동반되었다. 이환된 부비동의 빈도 순은 상악동 사골동, 전두동, 접형동 순이었다.

\section{비강으로의 탈출경로}

48 명의 환자 중 자연공을 통한 경우는 27 명 $(56.3 \%)$ 부공을 통한 경우는 20명(41.7\%)이었으며, 1 명(2\%)은 이전의 수술로 인한 중비도 개창부를 통해 비강으로 빠 져 나왔다.

\section{비용의 기시부위}

상악동 후비공 비용이 기시한 부위는 기록이 미비하거 나 기시부위를 정확히 알 수가 없는 17 명을 제외한 31 명 을 대상으로 조사하였다. 상악동 점막의 외측벽 10명, 전

Table 2 Origin wall of maxillary sinusin antrochoanal polyp

\begin{tabular}{lc}
\hline \multicolumn{1}{c}{ Origin } & No. (\%) \\
\hline Lateral & $10(32.3)$ \\
Anterior & $5(16.1)$ \\
Posterolateral & $4(12.9)$ \\
Posteroinferior & $3(9.7)$ \\
Posterior & $3(9.7)$ \\
Inferior & $3(9.7)$ \\
Medial & $1(3.2)$ \\
Superior & $1(3.2)$ \\
Inferolateral & $1(3.2)$ \\
\hline Total & $31(100)$ \\
\hline
\end{tabular}

Table 3. Operative technique of antrochoanal polyp according to origin

\begin{tabular}{lcc}
\hline \multirow{1}{*}{ Origin } & \multicolumn{2}{c}{ Operative technique } \\
\cline { 2 - 3 } & $\begin{array}{c}\text { Conventional } \\
\text { ESS }\end{array}$ & $\begin{array}{c}\text { Puncture and } \\
\text { shaving }\end{array}$ \\
\hline Lateral & $7(30.4)$ & $3(37.5)$ \\
Anterior & $2(8.8)$ & $3(37.5)$ \\
Posterolateral & $3(13.0)$ & $1(12.5)$ \\
Posteroinferior & $3(13.0)$ & \\
Posterior & $3(13.0)$ & $1(12.5)$ \\
Inferior & $3(13.0)$ & \\
Medial & $1(4.4)$ & \\
Superior & $1(4.4)$ & \\
\hline Total & $23(100)$ & \\
\hline ESS: Endoscop)
\end{tabular}

ESS : Endosc opic sinus surgery
벽에서 5명, 후외측벽 4 명, 후하벽 3명, 후벽 3명, 하벽 3 명, 내측벽 1 명, 상벽 1 명, 하외측벽 1 명이었다(Table 2).

\section{수술적 접근법과 상악동후비공용종 기시부의 관계}

48명의 환자 모두에서 부비동 내시경수술을 시행하였 고 그 중 12 명의 환자는 보조적으로 견치와 천공을 통해 회전식흡입기를 사용한 상악동내시경수술 즉 "puncture and shaving" 기법을 사용하였다. "puncture and shaving” 기법을 통해 수술한 환자 중 기시부를 알 수 있었던 환자 8 명에서, 전벽점막 기원이 3 명, 외측벽 3 명, 후외 측벽 점막 1 명, 하벽 점막에서 기원한경우가 1 명으로 기 존의 부비동내시경수술만으로는 제거하기 어려운 전벽과 외측벽 점막에서 기원한 경우가 많았다. 기존의 부비동 내시경수술을 시행한 환자 중에서 기시부를 알 수 있었 던 23명중 내측벽 점막기원이 1 명, 상부점막 1 명, 외측 벽 7 명, 전벽 2 명, 하벽 3 명, 후벽 3 명, 후외측벽 3명, 후하벽 3명으로 비교적 후방이나 외측벽 점막에서 기원 한 경우가 많았다(Table 3 ).

\section{합병증}

수술 후 일시적인 안면부의 부종과 통증은 있었으나 안 면부나 치아의 감각저하와 천공부위의 염증, 비출혈 등 의 합병증은 없었다.

\section{재발여부}

수술 후 추적관찰 중 10 명이 재발하였으며, 알레르기 와 부비동염의 동반여부에 따른 재발율의 차이는 없었 다. 재발한 기간은 수술 후 3 17개월(평균 11.1 개월)이 었으며, 재발한 10 명 중 9 명은 부비동내시경수술만을 시 행 받은 환자였고 1 명은 "puncture and shaving" 기법 을 시행 받은 환자였으며 수술 후 재발율은 "puncture and shaving" 기법을 시행 받은 환자에서 의미있게 낮 았다 $(\mathrm{p}<0.001)$. 재발한 환자에서 기시부위를 알 수 있 었던 환자는 부비동내시경수술만을 시행 받은 7 명이었 으며, 하벽 1 명, 후하벽 1 명, 외측벽 3 명, 전벽 2 명으로 전벽과 하벽, 그리고 외측벽 점막에서 기원한 경우가 많 았다. 재발한 환자 중 4 명은 외래에서 touch-up procedure로 치료하였으며 2명은 재수술을 실시하였다. 외래 에서 시술받은 환자 4 명과 재수술을 시행 받은 환자 2 명 은 1 년 이상 장기 추적결과 재발 소견이 관찰되지 않았다. 


\section{고 찰}

상악동 후비공 비용은 일반적인 단순 비용과는 다르 게 여자보다는 남자에서, 성인보다는 소아에서 많이 이환 되며, 주로 일측성으로 발생한다고 알려져 있다. ${ }^{13) 6)}$ 본 연구에서도 전체 48 예 중 양측성 1 예를 제외하고 44 예 가 일측성 이었으며, 남자(32예)가 여자(16예)보다 2배 정도 많았고 15세 이하 소아가 30예(62.5\%)로 성인보 다 많은 분포를 차지하여 다른 연구결과와 일치하였다.

주요증상으로는 비폐색, 비루, 후각장애, 재채기 등이 있고 드물게 비출혈이나 협부 압통을 호소할 수 있다. ${ }^{34)}$ 본 연구에서도 주요 증상으로는 일측성 비폐색이 $81 \%$ 에서 관찰되어 가장 흔한 증상이었으며, 그 외 비루, 후 비루, 비출혈, 코골이 등의 증상이 나타났으며, 이러한 결 과로 보아 상악동 후비공 비용의 가장 중요한 주증상은 일측성 비폐색으로 생각된다.

상악동 후비공 비용의 발생 원인에 있어서 알레르기의 역할은 과거에는 거의 영향이 없는 것으로 알려져 있지 만 최근의 몇몇 연구에서는 상악동 후비공 비용의 50 $69 \%$ 에서 알레르기를 동반한다고 보고하였다. ${ }^{13) 14)}$ 본 연 구에서도 MAST, 비세포검사, 혈청 총 $\operatorname{IgE}$ 검사를 통해 $61.3 \%$ 에서 특정 알레르기 항원에 양성반응을 보여 상악 동 후비공 비용의 병인에 알레르기가 관여할 수 있음을 보여주었다. 하지만 알레르기 동반 유무에 따른 수술 후 재발율에는 특별한 차이를 보이지 않아 재발에는 특별한 영향이 없는 것으로 생각되었다.

만성부비동염의 경우 $\mathrm{Chu}$ 등 ${ }^{15)}$ 은 비 · 부비동 전산화 단층 촬영과 내시경으로 판단한 부비동 점막의 병변이 전 사골동, 상악동, 후사골동, 전두동, 접형동 순이었으며 모 든 부비동 점막에 다 병변이 있는 경우도 $39.2 \%$ 였다고 하였다. 본 연구에서도 상악동염을 제외한 부비동염이 동 반된 경우가 19 명이었으며, 이는 상악동 후비공 비용이 만성 부비동염과 무관하지 않다는 것을 보여 준다고 할 수 있다. 특히 상악동염이 가장 많은 것으로 보아 상악동 후비공 비용이 상악동염을 악화시키는 인자로 작용할 수 도 있다고 생각된다.

상악동 후비공 비용은 상악동에서 자연공이나 부공을 통하여 비강으로 자라난다. Purna 등 ${ }^{16)}$ 은 관찰한 모든 경우에서 부공을 통하여 자란 것으로 보고하였고, Ozdek
등 $^{1)}$ 은 10 명의 환자에서 7 명은 자연공을 통해서 3 명은 부공을 통해서 비강으로 나온다고 보고하였다. 본 저자 들이 경험한 총 48 예에서는 자연공을 통한 경우가 $56.3 \%$, 부공을 통한 경우가 $41.7 \%$ 로 자연공을 통해서 비강으로 돌출된 경우가 더 많았다.

상악동 후비공 비용의 외과적 치료시 가장 중요한 점은 비용의 모든 부분의 완전한 제거에 있으며 만약 잔존 비 용조직이 남아있을 경우 재발하는 경우가 많다. 그러므로 상악동 후비공 비용을 성공적으로 제거하기 위해서는 후 비공 비용의 기시부위를 파악하는 것이 가장 중요하다. 상 악동 후비공 비용에서 상악동은 대개 비후되고 비용성 조 직으로 차 있어 기시부위를 명확히 알 수 없는 경우도 있어 본 연구에서는 총 48 명의 환자 중 31 명에서만 비 용의 기시부위에 대해 알 수 있었다. 상악동내 비용은 후 벽과 하벽에서 가장 많이 발생한다는 보고도 있고, ${ }^{11)}$ 측벽이 가장 흔한 발생 부위라는 보고도 있다. ${ }^{2) 3)}$ 본 연 구에서도 비용의 기시부위를 알 수 있는 환자의 $32.3 \%$ 에서 측벽에서 발생하여 측벽이 가장 흔한 기시부위인 것 을 알 수 있었다.

수술방법으로 과거에는 주로 단순결출술, Caldwell Luc 수술, 골성형 상악동수술 그리고 하비도 동절개술이 주 로 사용되었으나 이들은 비교적 재발율이 높거나 술 후 후유증 등이 발생하게 되는 경우가 많아 최근들어 상악 동 후비공 비용 수술방법으로 술후 합병증이 적고 안전 하며 쉽게 사용할 수 있는 부비동내시경수술이 많이 사 용되고 있다. ${ }^{4) 8)}$ 하지만 상악동 전벽 또는 측벽에서 기 원하는 상악동 후비공 비용의 경우 자연공을 통한 기본 적인 술식으로는 상악동 내부의 병변을 완전히 제거하기 쉽지 않은 경우가 많으며 이러한 경우 남아있는 병적 점 막으로 인해 재발할 수 있다. 상악동 전벽이나 측벽에 존 재하는 비용이나 병적 점막을 제거하기 위해 상악동의 자 연공을 무리하게 전하방으로 확장시킬 경우 비루관 손 상으로 인한 유루증 등 합병증을 일으킬 가능성도 있어 이러한 경우 기존의 Caldwell Luc 수술을 선택하게 되 는 경우가 많았다. 하지만 이 술식은 술후 회복 기간이 느리고 협부 종창이나 협부 감각이상, 치아 손상 등을 초 래 할 수 있다. 특히 소아에서 높은 빈도를 보이는 상악 동 후비공 비용의 치료에 있어서는 수술 후유증외에 치 아의 발육장애와 안면골 성장장애 등을 동반할 수 있으 므로 바람직하지 못하다. ${ }^{2) 6)}$ 부비동 내시경 수술과 함 
께 견치와 접근법을 통한 남아 있는 상악동내 병변을 제 거하는 "puncture and shaving" 기법은 부비동 내시경 수술을 단독 사용했을때의 장점과 함께 중비도 접근법만 으로는 관찰하기 힘든 부위를 비교적 쉽게 관찰할 수 있 어 재발의 가능성을 줄일 수 있을 뿐 아니라 부비동 내시 경 수술 중 시야 확보가 안되는 부위의 치료를 위해서 Caldwell Luc 수술 등 다른 술식을 병행하지 않아도 된 다는 점에서 많은 잇점을 가지고 있다. 본 연구에서 부비 동내시경수술을 시행받은 48명의 환자 중 "puncture and shaving” 기법을 사용한 경우는 12 예였으며, 이중 병변 의 기시부를 알 수 있었던 환자 8명에서 병변 점막의 기 시부를 조사한 결과, 전벽에서 기원한 경우가 3 명, 외측 벽 3 명, 후외측벽 1 명, 하벽 1 명으로 기존의 부비동내시 경수술만으로는 제거하기 어려운 전벽 및 외측벽 부위에 서 기원한 경우가 많았으며, 수술 후 재발율도 부비동 내 시경 수술만을 시행받은 환자에 비해 의미있게 낮았다. 부비동내시경수술만을 시행한 환자는 주로 후방이나 외 측벽 점막에서 기원한 경우가 많았으며, 부비동 내시경 수술만 시행후 재발한 환자들은 주로 기시부위가 외측벽 과 전벽이어서 전벽이나 전벽에 접해 있는 외측벽에서 기 시한 상악동 후비공 비용의 경우에는 부비동 내시경 수 술만으로는 병변을 완전 제거하기가 어렵다는 것을 알 수 있었다.

상악동 후비공 비용의 수술 방법을 결정하기 전에 환자 의 나이, 동반된 부비동 질환의 유무, 이전의 수술 병력, 전산화 단층 촬영을 통한 상악동의 발달 정도를 확인하 여야 하며, 무엇보다도 비용의 기시부위를 분명히 확인한 후 비용을 완전히 제거하고 합병증을 최소화 할 수 있는 적절한 수술 방법을 찾는 것이 좋을 것으로 생각된다.

\section{결 론}

본 연구에서 상악동 후비공 비용의 술 후 재발에 알레 르기는 연관이 없지만 상악동 후비공 비용의 병인에 알 레르기는 연관성이 있다는 것을 알 수 있었다. 상악동 후비공 비용은 상악동의 외측 점막에서 가장 많이 기원 하였다. 병변의 기시부가 상악동 후벽이나 후벽에 가까 운 측벽인 경우는 부비동 내시경 수술 만으로도 병변의 완전 제거가 가능하지만 병변의 기시부가 전벽이거나 전 벽에 가까운 측벽인 경우는 "puncture and shaving" 기
법을 사용하여 비강 및 상악동의 병변을 완전히 제거함 과 동시에 정상적인 점막을 보존하고, 재발율을 낮출 수 있을 것으로 생각된다.

중심 단어 : 비용종 · 상악동 · 내시경 · 천공 · 분석.

본 연구는 2006년도 부산대학교병원 임상연구비 지원으로 이루어졌음.

\section{REFERENCES}

1) Ozdek A, Samim E, Bayiz U, Meral I, Safak MA, Oquz H. Antrochoanal polyps in children. Int J Pediatr Otorhinolaryngol 2002;65:213-8.

2) Basak S, Karaman CZ, Akdilli A, Metin KK. Surgical approaches to antrochoanal polyps in children. Int J Pediatr Otorhinolaryngol 1998;46:197-205.

3) Woolley AL, Clary RA, Lusk RP. Antrochoanal polyps in children. Am J Otolaryngol 1996;17:368-73.

4) Kim YD, Bai CH, Kim JW, Chung YS, Suh JS, Song KW. Endoscopic sinus surgery of antrochoanal polyp. Korean $J$ Otolaryngol 1998;41 (2):208-12.

5) Lee JY, Kim KH, Lee YM, Kim HJ, Byun JY, Koh YW, et al. Analysis of complications after endoscopic maxillary sinus surgery with canine fossa puncture and microdebrider. Korean J Otolaryngol 2006;49:303-6.

6) Kwon SH, Kim KM, Kim W. The role of endoscopic sinus surgery with transcanine approach in antrochoanal polyps. Korean J Otolaryngol 2000;43:956-60.

7) Busaba NY, Kieff D. Endoscopic sinus surgery for inflammatory maxillary sinus disease. Laryngoscope 2002;112: 1378-83.

8) Sato K, Nakashima T. Endoscopic sinus surgery for chronic sinusitis with antrochoanal polyp. Laryngoscope 2000;110: 1581-3.

9) Ahn CM, Choi JH, Park MG, Shin YH, Kim DR. Classification of antrochoanal polyp according to the extension. Korean J Otolaryngol 2004;47:238-42.

10) Chung SK, Lee CK, Lee HS. Sinus CT findings of antrochoanal polyp. Korean J Otolaryngol 2003;46:54-8.

11) Min YG, Chung JW, Shin JS, Chi JG. Histologic structure of antrochoanal polyps. Acta Otolaryngol 1995;115:543-47.

12) Shin SH, Kim CG, Ye MK, Shin DW, Kim WS. Effect of pediatric endoscopic sinus surgery with antrochoanal polyps on sinus growth. Korean J Otolaryngol 2005;48:615-8.

13) Cook PR, Davis WE, McDonald R, Mckinsey JP. Antrochoanal polyposis: a review of 33 cases. Ear Nose Throat $J$ 1993;72:401-10.

14) Chen JM, Schloss MD, Azouz ME. Antro-choanal polyp: $a$ 10-year retrospective study in the pediatric population with a review of the literature. J Otolaryngol 1989;18:168-72.

15) Chu CT, Lebowitz RA, Jacobs JB. An analysis of sites of disease in revision endoscopic sinus surgery. Am J Rhinol 197;11:287-91.

16) Pruna X, JM Ibanez, Serres X, Garriga V, Barber I, Vera J. Antrochoanal polyps in children: Ct findings and differential diagnosis. Eur Radiol 2000;10:849-51. 